Research Report No. 43/2012

\title{
The Globalization of Tax Expenditure Reporting: Transplanting Transparency in India and the Global South
}

Lisa Philipps

Osgoode Hall Law School of York University, lphilipps@osgoode.yorku.ca

Follow this and additional works at: http:// digitalcommons.osgoode.yorku.ca/clpe

\section{Recommended Citation}

Philipps, Lisa, "The Globalization of Tax Expenditure Reporting: Transplanting Transparency in India and the Global South" (2012). Comparative Research in Law \& Political Economy. Research Paper No. 43/2012.

http://digitalcommons.osgoode.yorku.ca/clpe/34 


\section{OSGOODE}

OSGOODE HALL LAW SCHOOL YOR K U N I VERSITY

\section{OSGOODE HALL LAW SCHOOL}

Comparative Research in Law \& Political Economy

RESEARCH PAPER SERIES

Research Paper No. 43/2012

The Globalization of Tax Expenditure Reporting: Transplanting Transparency in India and the Global South

Lisa Philipps

\section{Editors:}

Peer Zumbansen (Osgoode Hall Law School, Toronto, Director Comparative Research in Law and Political Economy)

John W. Cioffi (University of California at Riverside)

Leeanne Footman (Osgoode Hall Law School, Toronto, Production Editor)

Comparative Research in Law \& Political Economy 
*The final version of this article is forthcoming in Yariv Brauner and Miranda Stewart, eds., Tax Law and Development (Cheltenham, UK: Edward Elgar Publishing Ltd.)

\title{
The Globalization of Tax Expenditure Reporting: Transplanting Transparency in India and the Global South
}

\author{
Lisa Philipps ${ }^{\circledR}$
}

\section{Introduction}

This chapter traces the rise of tax expenditure reporting in countries of the Global South, with a particular focus on India. It investigates why and how policy makers in some low and middle income countries are now moving to adopt a budgeting practice that originated in wealthy Western nations in the 1970s. I discuss the potential advantages of this trend, but also argue that there is a need for its champions to face up to some challenges and potential disadvantages of transplanting this form of fiscal transparency into different national contexts. These include methodological and political challenges that are well known to Western observers but are seldom fully acknowledged in the literature advocating adoption of tax expenditure reporting by developing countries. In addition, the chapter questions whether generic prescriptions are sufficiently attuned to local political, economic and institutional circumstances that may diminish the value of OECD-style tax expenditure reporting to receiving countries.

Part II briefly reviews the history of tax expenditure analysis since the late 1960s and then charts the more recent campaign to encourage its implementation by developing countries. The analysis shows that international organizations, Western commentators, and domestic tax policy experts have all contributed to this campaign. Advocates have tended to rely on two main types of rationale. The first is technocratic, stressing the value of tax expenditure reporting to government policy makers seeking to craft a more efficient, equitable and administratively simple tax system which raises maximum revenues to finance state priorities. The second focuses more on democratic governance and the role of transparency in securing accountability for the allocation of public resources and distribution of tax burdens. Part II concludes by reviewing the evidence that there is indeed a modest trend toward the globalization of tax expenditure reporting.

Part III offers a case study of India's experience leading up to the publication of its first tax expenditure report in 2006 and how this report has developed through several budget cycles. The case study shows that a mix of internal and external influences were at play in bringing this budget document to India. It also compares the Indian report to Canada's tax expenditure report and finds that the Indian exercise is more robust from both technocratic and democratic perspectives. Part III highlights both the potential benefits of tax expenditure reporting in India and its limits. While the tax expenditure report provides new and valuable information and analysis, there are significant political and institutional barriers to translating this knowledge into significant tax reforms.

In Part IV, I suggest several reasons why foreign experts and international organizations ought to choose our words carefully in recommending tax expenditure analysis to countries of the Global South. Law and development literature has documented the problems that can arise when institutional reform prescriptions are not sufficiently contextualized to local politics, economies and culture. I argue that these concerns apply with equal force to the quest for universal tax expenditure reporting. At a minimum, advocates should openly acknowledge that tax expenditure analysis remains contested and has limited political purchase in the OECD countries usually held out as models of best practice. Caution is also needed to ensure that normative biases about ideal tax policy are not smuggled in through an ostensibly technocratic exercise in transparency, thereby distorting or sidestepping the domestic policy making processes of the receiving country. Finally, before investing scarce administrative resources in a particular

\footnotetext{
(๑) Professor, Osgoode Hall Law School and Associate Vice-President Research, York University, Toronto, Canada (philipps@yorku.ca).
} 
model of tax expenditure reporting developing countries should be encouraged to weigh its potential benefits and costs, including the opportunity costs of foregoing other possible activities of finance and revenue personnel. I argue that without an explicit strategy for naming, analyzing and tackling these challenges as they arise in context, tax expenditure reporting is even less likely to impact positively on either policy formation or democratic accountability than in the high income countries where it was first established.

Part V concludes by summarizing the potential benefits but also the likely limitations and costs of tax expenditure reporting as a development strategy.

\section{Tax Expenditure Reporting: From U.S. Origins to Global Relevance}

Since the late 1960s tax policy analysts in the US and other industrialized countries have drawn an analytical distinction between on the one hand the normal or technical rules of a tax which are designed to raise revenues in an equitable and efficient manner, and on the other the special concessions or targeted exceptions from the normal rules which are designed to achieve other economic or social policy goals of government. Stanley Surrey, as Harvard Professor and Assistant Secretary to the US Treasury, famously coined the term "tax expenditures" to describe this second dimension of a tax system and to make the point that these exceptional provisions should be understood not as tax rules at all but as indirect spending programs. ${ }^{1}$ When governments wish to address market failures or stimulate changes in economic or social behavior, they can choose from a suite of policy instruments including soft or hard regulation, direct service provision, money transfers, or tax measures. ${ }^{2}$ Surrey argued that deciding to tax a particular group or economic activity more lightly than others in order to achieve such goals is financially equivalent to providing a direct grant to the taxpayers who benefit. Thus, they should be designed and evaluated with the same care as direct spending programs.

Tax expenditure reporting is the remedy that Surrey prescribed to address the transparency problems created by delivering spending programs indirectly through the tax system. Accountability of government institutions for the expenditure of public funds is typically identified as a basic requirement of the rule of law. ${ }^{3}$ Thus information about the objectives, cost, target effectiveness, and distributional impact of any public spending program in principle should be available for review by democratic institutions of the state and civil society. However tax expenditures often escape this type of scrutiny because they are embedded within highly technical provisions of a tax law that generally need never be re-approved once enacted. Over time, these preferences and deviations from the normal tax system can come to be seen as part of a complex revenue raising structure rather than spending programs which should be costed and reviewed like any other government expenditure. Surrey's proposed solution to counteract this relative invisibility was to embed tax expenditure reporting within the budgetary process. That is, the budget should include information about the foregone revenues and other impacts associated with tax expenditures to facilitate cost-benefit analysis of individual measures and trade-offs with other uses of public money. In addition to improving transparency about the total spending budget, Surrey hoped that exposing the inequities, inefficiencies and administrative complexities of tax expenditures would provide impetus for base-broadening tax reforms. ${ }^{4}$

\footnotetext{
${ }^{1}$ See Stanley S. Surrey, Pathways to Tax Reform: The Concept of Tax Expenditures (Harvard University Press, 1973); and Stanley S. Surrey and Paul R. McDaniel, Tax Expenditures (Harvard University Press, 1985). The history of Surrey's work through the late 1960s and 1970s, much of it with Professor Paul McDaniel, is reviewed in J. Clifton Fleming Jr. and Robert J. Peroni, 'Reinvigorating Tax Expenditure Analysis and its International Dimension' 27 Virginia Tax Review 437 (2008), 439-441.

${ }^{2}$ See Surrey, Ibid., 3; and Surrey and McDaniel, Ibid, 25-26.

${ }^{3}$ See, e.g., Michael J. Trebilcock and Ronald J. Daniels, Rule of Law Reform and Development: Charting the Fragile Path of Progress (Edward Elgar, 2008), 32.

${ }^{4}$ United States, Staff of the Joint Committee on Taxation, A Reconsideration of Tax Expenditure Analysis, JCX-3708 (U.S. Government Printing Office, May 12, 2008), 2-3. See also Surrey, supra n. 1, 30-33.
} 
*The final version of this article is forthcoming in Yariv Brauner and Miranda Stewart, eds., Tax Law and Development (Cheltenham, UK: Edward Elgar Publishing Ltd.)

Under Surrey's influence the US government began publishing tax expenditure data in $1968 .^{5}$ Since then the basic principles and ideals of tax expenditure analysis have been accepted by many Western tax policy analysts inside and outside government and by international bodies that are influential in developing fiscal policy norms (as discussed further below). Tax expenditure reporting is a well established practice in many OECD countries, some of which require it by law. ${ }^{6}$ It also has fierce critics. Especially in the US, an entrenched debate persists about the basic coherence of the concept and whether it is possible in a clear and principled way to distinguish the normative tax system of a country from the exceptions to it. Surrey and McDaniel defined their benchmark tax in relation to the Schanz-Haig-Simons concept of economic income as the sum of the value of a person's consumption plus the change in their net wealth over a period of time. ${ }^{7}$ Some critics have rejected their choice of benchmark as a thinly veiled political agenda to reform the tax system in accordance with a particular model, while others argue that it is too vague to resolve the classification of many provisions. ${ }^{8}$ In a recent comparative study of OECD countries Christopher Heady noted there is in fact significant variation among countries in the choice of benchmarks. ${ }^{9}$ Beyond this fundamental definitional question other controversies abound over how to measure the costs, distributional impacts, and behavioural effects of tax expenditures, and whether estimates of revenue foregone from tax expenditures are so uncertain and contingent that they are more likely to mislead than to enlighten the public. ${ }^{10}$

Despite these ongoing debates, many tax commentators accept the basic principles and ideals of tax expenditure analysis. Their most frequent lament is that it has had such limited impact on policy making in OECD countries. Academic scholars and other budget analysts have frequently complained about the lack of depth and detail in tax expenditure reports, the failure of policy makers to integrate tax expenditure analysis fully into budgetary decision making or tax law design, and the rapid growth of tax expenditures in number and cost despite the availability of information about them. ${ }^{11}$ These and other problems led the Staff of the Joint Committee on Taxation of the U.S. Congress to conclude in 2008 that

\footnotetext{
${ }^{5}$ United States Treasury, Annual Report of the Secretary of the Treasury on the State of the Finances for the Fiscal Year ended June 30, 1969 (U.S. Government Printing Office, 1969), 330, available as of February 12, 2012, at http://www.archive.org/details/annualreportofse1969statiunit.

${ }^{6}$ See, e.g., Australia's Charter of Budget Honesty Act, 1998, pt. 5, div. 1, s.12(1)(d), and the U.S. Congressional Budget and Impoundment Control Act 1974. See also OECD, Tax Expenditures in OECD Countries (OECD, 2010); OECD, Tax Expenditures: Recent Experiences (OECD, 1996); and OECD, Tax Expenditures: A Review of Issues and Country Practices (OECD, 1984).

${ }^{7}$ Henry Simons, Personal Income Taxation: the Definition of Income as a Problem of Fiscal Policy (University of Chicago Press, 1938).

${ }^{8}$ See Boris I. Bittker, “A “Comprehensive Tax Base” as a Goal of Income Tax Reform' 80:5 Harvard Law Review 925 (1967), and 'Accounting for Federal "Tax Subsidies" in the National Budget' 22:2 National Tax Journal 244261 (1969).

${ }^{9}$ Christopher Heady, 'Tax Expenditures: Definitional and Policy Issues,' in Lisa Philipps, Neil Brooks, and Jinyan Li, eds., Tax Expenditure Analysis: State of the Art (Canadian Tax Foundation, 2011).

${ }^{10}$ Paul McDaniel recently reviewed and responded to these criticisms in 'The Staff of the Joint Committee on Taxation Revision of Tax Expenditure Classification Methodology: What Is To Be Made of a Change That Makes No Changes?' in Lisa Philipps, Neil Brooks, and Jinyan Li, Ibid. Ch. 3. For a revealing discussion of how debate over the benchmark has undermined the political effectiveness of tax expenditure analysis, see Victor Thuronyi, 'Tax Expenditures: A Reassessment' Duke Law Journal 1155 (1988). For a thorough discussion of the critiques and a response in defense of tax expenditure analysis, see Fleming and Peroni, supra n. 1, 487-525.

${ }^{11}$ Some recent examples include Robin Boadway, 'The Annual Tax Expenditure Reports—A Critique' 55:1 Canadian Tax Journal 106 (2007); Mark Burton, 'Making the Australian Tax Expenditures Statement an Effective Policy Instrument: From Fiscal Record to Transparent Report' 8 (1) Australian Journal of Taxation 1(2005); Edward Kleinbard, 'The Congress Within the Congress: How Tax Expenditures Distort Our Budget and Our Political Processes' 36 Ohio Northern Law Review 1 (2010); and Emil Sunley, 'Tax Expenditures in the United States: Experience and Practice,' in Hana Polackova Brixi, Christian M.A. Valenduc, and Zhicheng Li Swift, eds., Tax Expenditures—Shedding Light on Government Spending Through the Tax System: Lessons from Developed and Transition Economies (The International Bank for Reconstruction and Development/The World Bank, 2004), 155.
} 
"Surrey's original hope that tax expenditure analysis would have a salutary effect on budget transparency (and through that, on actual budget outlays) has not been realized...". ${ }^{12}$

Similar disappointments have been expressed by leading international organizations, which have served as key interlocutors in the effort to globalize tax expenditure analysis. First among these is the Organization for Economic Cooperation and Development (OECD), widely recognized as the dominant player in the formation of global tax policy norms. ${ }^{13}$ The OECD has been critical of the proliferation of tax expenditures based on its view that the most efficient tax system in a market economy has a broad base and low rates applied neutrally to different forms of income or economic activity. It has reiterated this concern recently:

Accounting in many countries suggests that the use of tax expenditures is pervasive and growing...At any time, the possibility that a back channel for resource allocation could lead to inefficient government "spending" would be troubling. When many government budgets are threatened by population ageing and adverse cyclical developments [i.e. deficits], the concern is only greater. ${ }^{14}$

The OECD has accordingly sought to encourage critical analysis of tax concessions at the country level. For example, its Best Practices for Budget Transparency provides that " $\mathrm{t}] \mathrm{the}$ estimated cost of key tax expenditures should be disclosed as supplementary information in the budget...in order to inform budgetary choices". ${ }^{15}$ Importantly, it does not limit its advocacy to OECD countries. Rather, the Best Practices are explicitly designed as a "reference tool for Member and non-Member countries." ${ }^{16}$ Thus the OECD promotes tax expenditure reporting as a universal good. I describe its approach as technocratic because it focuses on assisting government actors to make better policy, as measured against the OECD's standards of an ideal tax system.

Both the IMF and the World Bank have reinforced the OECD's message and directed it more pointedly at low and middle income countries. Both of these bodies have more power than the OECD to intervene and produce policy change at the country level, for example through loan conditionality, surveillance reporting, and provision of technical assistance to design and implement reforms. The IMF's Code of Good Practices on Fiscal Transparency says that every country's budget should disclose "the nature and fiscal significance of central government tax expenditures." ${ }^{17}$ The IMF publishes reports (the so-called "Fiscal ROSCs") on individual countries' compliance with this Code. ${ }^{18}$ The importance of presenting tax expenditure estimates to Parliament, "preferably as part of annual budget documentation" was reiterated recently in a Technical Guidance Note prepared by IMF staff. ${ }^{19}$

Policy analysts have elaborated several rationales for advocating that lower income and transition countries embrace the kinds of tax expenditure reporting practiced in high income countries. These include a mix of technocratic arguments aimed at policy makers, and more accountability-oriented rationales that speak to democratic governance of the budget process in developing countries. Thus World Bank analyst Schiavo-Campo warns that concessions granted through tax laws "are not submitted to the same system of internal control and legislative authorization as other expenditures," and that tax

\footnotetext{
${ }^{12}$ Supra note 4.

${ }^{13}$ For a detailed discussion of the OECD's leadership role in international tax policy standard setting, see Allison Christians, 'Networks, Norms and National Tax Policy' Wash. U. Global Studies Law Review (2010).

${ }^{14}$ Tax Expenditures in OECD Countries, supra n. 6, 14.

${ }^{15}$ OECD Best Practices for Budget Transparency (OECD, May 15, 2001), s.2.2.

${ }^{16}$ Ibid., s.4.

${ }^{17}$ (IMF 2007), s.3.13.

18 The Fiscal ROSCs published to date can be viewed on the IMF's Fiscal Transparency webpage: http://www.imf.org/external/np/rosc/rosc.asp?sort=topic\#FiscalTransparency. For a full discussion of the IMF's limited vision of budget transparency, see Lisa Philipps and Miranda Stewart, 'Fiscal Transparency: Global Norms, Domestic Laws, and the Politics of Budgets' 34:3 Brooklyn Journal of International Law 797 (2009).

${ }^{19}$ Ian Lienert, 'Role of the Legislature in Budget Processes' (IMF Fiscal Affairs Department, April 2010), 13, available as of February 12, 2012, at http://blog-pfm.imf.org/files/fad-technical-manual-9.pdf.
} 
*The final version of this article is forthcoming in Yariv Brauner and Miranda Stewart, eds., Tax Law and Development (Cheltenham, UK: Edward Elgar Publishing Ltd.)

expenditure reporting "enhances legislative scrutiny of government policy". ${ }^{20}$ This scrutiny is in turn expected to improve the quality of tax policy because it will expose the ineffective, inefficient and inequitable character of many tax expenditures. It could reveal, for example, that "high-income households can benefit more than needier households from tax credits" and that the latter group would be better served by "family allowances targeted to low-income groups." ${ }^{21}$ Other commentators have linked the rise of tax incentives to problems of corruption and abuse of power in developing countries. Li Swift for example argues that tax incentives often create avenues for avoidance or evasion by wealthier taxpayers and for discretion-wielding officials to favour powerful interests. ${ }^{22}$ This connects to a larger concern about erosion of the state's capacity to raise revenues to finance development projects directly. For example a study of Poland's budget provided data to show that the "cost of tax expenditure programs ... has grown much faster than direct spending programs". ${ }^{23}$ Tax expenditure reporting is presented as a way to counteract this alarming trend:

...with limited theoretical understanding of, and ad hoc experience with, applying tax expenditures, developing countries now confront not only revenue losses higher than they had anticipated but also the erosion of their tax bases in systems that generally have been in existence fewer than 10 years. $^{24}$

Liberal use of tax incentives is blamed for "reducing these countries' capacity to assist the needs of the poor". ${ }^{25}$ Heavier scrutiny of tax expenditures is therefore recommended as part of a strategy to mobilize revenues for development spending in the interests of less powerful sectors of society.

Tax incentives for foreign investors and domestic industry have been particularly singled out by some commentators. For example Richard Krever has provided a strong critique of corporate income tax incentives in Mongolia and recommended that its government implement tax expenditure analysis as part of its policy making process. ${ }^{26}$ In previous work Miranda Stewart and I have made a similar argument that promoting transparency about not only the costs but the distributive impact of investment tax incentives could foster democratic debate about tax policy at the country level and build domestic support for basebroadening reforms. ${ }^{27}$

At least one high profile NGO has also been active in calling on developing countries to publicize information about their use of tax expenditures. In 2006 the International Budget Project (IBP), an arm of the Washington-based Centre on Budget and Policy Priorities, launched its Open Budget Index, an evaluation and ranking of the degree of budget transparency in low and middle income countries. One of the many factors which forms the basis for the ranking is whether a country's budget documentation

\footnotetext{
${ }^{20}$ Salvatore Schiavo-Campo, 'The Budget and Its Coverage,' in Anwar Shah, ed., Budgeting and Budgetary Institutions (The International Bank for Reconstruction and Development/The World Bank, 2007) 53, 81.

${ }^{21}$ Ibid. See also Zhicheng Li Swift, Hana Polackova Brixi, and Christian Vanenduc, 'Tax Expenditures: General Concept, Measurement and Overview of Country Practices,' in Hana Polackova Brixi, Christian M.A. Valenduc, and Zhicheng Li Swift, eds., Supra note 11, 5.

${ }^{22}$ Zhicheng Li Swift, 'Managing the Effects of Tax Expenditures on National Budgets,' World Bank Policy Research Paper 3927, May 2006, 11-13, available as of February 12, 2012, at http://wwwwds.worldbank.org/servlet/WDSContentServer/WDSP/IB/2006/05/23/000016406_20060523092056/Rendered/P DF/wps3927.pdf. Academic scholar Wilson Prichard has similarly argued that non-transparent tax expenditures fuel corruption in developing countries. See Wilson Prichard, 'Taxation and State Building: Towards a Governance Focused Tax Reform Agenda' (Institute of Development Studies, University of Sussex, Working Paper 2010: 341), 33-34.

${ }^{23}$ Carlos B. Cavalcanti and Zhicheng Li Swift, 'Poland: Reforming Tax Expenditure Programs,' in Brixi, Valenduc, and Li Swift, supra note 11, 211.

${ }^{24}$ Ibid., 1.

${ }^{25}$ Ibid., 2.

${ }^{26}$ Richard Krever, Reform of the Mongolian Corporate Income Tax (Development Alternatives, Inc. (DAI), for the USAID-financed Economic Policy Support Project, September 24, 2003), 12-14.

${ }^{27}$ Philipps and Stewart, supra note 18, 841-842.
} 
includes information on tax expenditures, and if so the quality of that information. ${ }^{28}$ The IBP's stated reasons for advocating greater fiscal transparency are heavily focused on democratic governance rather than bringing domestic policy into line with particular OECD standards. Instead, the IBP seeks to empower civil society groups inside and outside a country to question how public funds are being used and to apply political pressure for changes they believe are needed. A recent report by Burton and Stewart for the IBP discusses concrete ways that civil society advocates can use a tax expenditure report effectively in order to hold governments accountable for budgetary decisions. ${ }^{29}$ Constituencies may make different uses of available information depending on their priority issues, such as redressing poverty, fighting corruption, making government spending more efficient, ensuring foreign aid is used for its intended purposes, de-financing parties to a violent conflict, or improving environmental practices. ${ }^{30}$

It is difficult to quantify the practical effect of expert discourses such as those discussed above. However, it does appear that tax expenditure reporting has gained some traction in some low and middle income countries in the early part of the $21^{\text {st }}$ century. Based on data gathered by the OECD from 2007-09, 50 per cent of OECD member countries provided a "comprehensive table of tax expenditures" in their budget documents, while the same was true of 30 per cent of non-member countries surveyed. ${ }^{31}$ Further, between 2006 and 2008, the International Budget Project reported improved scores on tax expenditure reporting for 8 low or middle income countries, while only one country had a lower score. ${ }^{32}$ This pattern of incremental reform continued in the 2010 survey with 10 countries improving their performance, though 6 others received a lower grade for tax expenditure reporting than in the 2008 survey. ${ }^{33}$ Burton and Stewart provide abundant examples and sources to show how specific developing and emerging countries have begun reporting data, often quite recently. ${ }^{34}$ The impetus for such reforms is likely different in each country but Western influences of some kind are often readily apparent. In some cases international agencies or experts have pointedly recommended that a country should do more to disclose and analyze its use of tax expenditures. ${ }^{35}$ In others, domestic experts have invoked international models

\footnotetext{
${ }^{28}$ See Open Budget Questionnaire, question 45, available as of February 12, 2012, at http://internationalbudget.org/what-we-do/open-budget-survey/.

${ }^{29}$ Mark Burton and Miranda Stewart, Promoting Budget Transparency Through Tax Expenditure Management: A Report on Country Experience for Civil Society Advocates (June 3, 2011), esp. 64-68.

${ }^{30}$ This diversity of political agendas is apparent from the range of testimonials by civil society advocates on the website of the Open Budget Index, available as of February 12, 2012, at http://internationalbudget.org/what-wedo/open-budget-survey/advocacy/obsa/.

${ }^{31}$ OECD International Database of Budget Practices and Procedures (available as of February 12, 2012, at www.oecd.org/gov/budget/database), question 35. The non-OECD countries reporting on tax expenditures in their budget documents were Argentina, Brazil, Ethiopia, Fiji, Ghana, Israel, Kenya, Latvia, Malawi, Mauritius, Moldova, Mongolia, Morocco, Papua New Guinea, Philippines, Taiwan, Tajikistan, and Zimbabwe.

${ }^{32}$ See IBP Open Budget Index for 2006 and 2008, answers to question 45. The countries that improved their score were Argentina, Georgia, Ghana, Guatemala, India, Jordan, Kenya, and Turkey. Only Papua New Guinea had a decline in its score.

${ }^{33}$ The ten improved countries were Chile, Colombia, Guatemala, Indonesia, Kazakhstan, Mexico, Morocco, Philippines, Russia, and Ukraine. The countries receiving a lower grade for tax expenditure reporting than on the 2008 survey were Georgia, Ghana, India (down from 'a' to 'b' due to incomplete information about new tax expenditures in the budget year), Kenya, Peru, and Sri Lanka.

34 Burton and Stewart, supra n. 29.

${ }^{35}$ See, e.g., Krever's 2003 report on Mongolia's corporate income tax, supra n. 26. See also International Monetary Fund, Experimental Report on Transparency Practices: Argentina (April 15, 1999), which commented that "published information on extrabudgetary funds, tax expenditures, and contingent liabilities is partial or unavailable' (para. 11). Based on data in their Open Budget Index Questionnaires, both Argentina and Mongolia have increased their reporting of tax expenditures since 2006.
} 
*The final version of this article is forthcoming in Yariv Brauner and Miranda Stewart, eds., Tax Law and Development (Cheltenham, UK: Edward Elgar Publishing Ltd.)

and standards to help make the case for reform. ${ }^{36}$ India provides a prime example of a country that has embraced tax expenditure reporting in a significant way in recent years.

\section{Tax Expenditure Reporting in India, 2006-2011}

For decades, Indian tax policy experts have been calling for greater scrutiny of tax expenditures within their country. In 1974, not long after Stanley Surrey pioneered the concept in the U.S., Anand Bagchi wrote that "[n]o one familiar with the Indian tax scene would fail to perceive how urgently the Indian income tax needs [tax expenditure analysis]...". ${ }^{37}$ A decade later Anand P. Gupta took up the cause arguing that the Indian tax system is "honeycombed with tax expenditures" and that "there is no proper system of accounting" for their costs. ${ }^{38}$ Gupta laid out glaring examples of concessions that were outdated, ineffective, or prone to abuse by tax avoiders, and proposed a serious review based on the following questions:

How much assistance does this tax expenditure provide? Does the activity benefiting from this tax expenditure continue to be high on the national agenda? Does the tax route continue to be the better way of assisting this activity? Has this tax expenditure been misused? ... Has it added to the costs of tax administration and made the tax system more complex and irrational? Who has benefited from it? Has it encouraged extravagance or waste? ...Has it been used to avoid or evade taxes? A periodical review along these lines would help in removing tax expenditures which serve little purpose. ${ }^{39}$

A series of government-appointed tax reform commissions returned to this theme repeatedly through the 1990's and early 2000's. ${ }^{40}$ In 2002 the Kelkar Task Force Report on Direct Taxes decried what it famously called the "exemption raj", arguing that overuse of tax incentives was distorting economic behavior, eroding revenues, draining administrative resources, and promoting corruption and abuse. ${ }^{41}$ The Task Force concluded that tax concessions are "not an efficient way of achieving...developmental objectives" and recommended broadening the tax base to finance a higher level of direct expenditures on public goods "particularly in the areas of health, education and other social infrastructure". ${ }^{42}$ Indian scholars also published several studies around this time criticizing the country's continued reliance on a complex web of exemptions and tax holidays in the face of abundant evidence of misuse and other active harms to the fairness and efficiency of the tax system. ${ }^{43}$

The passage of the Fiscal Responsibility and Budget Management Act ("FRBM") in 2003 contributed to the momentum for tax expenditure reporting. ${ }^{44}$ While the FRBM does not require tax

\footnotetext{
${ }^{36}$ See, e.g., M. Golam Mortaza and Lutfunnahar Begum, 'Tax Expenditures in Bangladesh: An Introductory Analysis' (Policy Analysis Unit, Bangladesh Bank, 2006), which draws heavily on IMF and World Bank literature in advocating that Bangladesh should improve its tracking and reporting of tax expenditures.

37 'Efficacy of Tax Incentives: "Tax Expenditure Analysis" and its Relevance for India' 9:24 Economic and Political Weekly 951(1974), 952.

38 'Management of Tax Expenditures in India' 19:47 Economic \& Political Weekly M-122 (1984), M-122 and M127.

${ }^{39}$ Ibid., M-130.

${ }^{40}$ See the Reports of the Tax Reforms Committee headed by Raja Chelliah (1991-93), the Shome Committee, and the Kelkar Task Force on Direct Taxes (2002), as discussed in Amaresh Bagchi, R. Kavita Rao, and Bulbul Sen, 'Raising the Tax-Ratio by Reining in the "Tax Breaks:" An Agenda for Action,' National Institute of Public Finance and Policy Working Paper No. 54 (December 2005), available, as of February 12, 2012, at

http://www.nipfp.org.in/newweb/sites/default/files/wp05_nipfp_tr_038.pdf.

${ }^{41}$ Dr. Vijay L. Kelkar et al, Report of the Task Force on Direct Taxes (New Delhi: December 27, 2002), 11-12 and 64-113, available as of February 12, 2012, at

http://www.prsindia.org/uploads/media/DTC\%20Bill/kelkar\%20direct\%20taxes.pdf.

42 Ibid., 12.

${ }^{43}$ See, e.g., Bagchi, Rao, and Sen, supra n. 40; same authors 'Tax Breaks for the Small Scale Sector' (May 2006); and M. Govinda Rao and R. Kavita Rao, 'Trends and Issues in Tax Policy and Reform in India' (October 2005).

${ }^{44}$ Fiscal Responsibility and Budget Management Act, No.39 of 2003, Gazette of India (2003).
} 
expenditure reporting per se it sets out targets for deficit reduction and requires more generally that the central government "shall take suitable measures to ensure greater transparency in its fiscal operations in the public interest...." 45

The Indian Ministry of Finance released its first tax expenditure report with the Union Budget of 2006-07, providing estimates of the revenue cost of various concessions to corporations, cooperatives and individuals. ${ }^{46}$ It also analyzed the gap between statutory and effective corporate tax rates and how the effective rate varied among larger and smaller corporations depending on the generosity of tax concessions available to them. ${ }^{47}$ This is notable because many OECD countries, including Canada, do not attempt any such distributive analysis in their tax expenditure reports but simply estimate the aggregate cost of each concession. ${ }^{48}$ The tax expenditure exercise was repeated in 2007-8 along with the following celebratory comment in the budget:

A tax expenditure or a revenue foregone statement was laid before Parliament for the first time during Budget 2006-07...It was well received by all quarters and gave rise to constructive debates on the entire gamut of issues concerning fiscal policy. It also lent credence to the Government's intention of bringing about transparency in the matter of tax policy and tax expenditures. ${ }^{49}$

The government's third tax expenditure report, released with the 2008-09 budget, expanded the distributive analysis by comparing effective tax rates in different industrial sectors. It found that the corporate tax burden was higher on public companies than privately owned ones, and higher on the manufacturing sector than the service sector. ${ }^{50}$ The report concluded with the following openly normative statement:

...the amount of revenue foregone continues to increase year after year. As a percentage of aggregate tax collection, revenue foregone remains high even though a declining trend is noticeable. This trend reflects the success of the tax reforms undertaken by the Government during the last four years. Moderate tax rates and base expansion are the two essential elements of such tax reforms. ${ }^{51}$

The 2009-10 and 2010-11 Statements of Revenue Foregone have adopted a sterner and less selfcongratulatory tone:

... As a percentage of aggregate tax collection, revenue foregone remains high and shows an increasing trend as far as Corporate Income-tax is considered for the financial year 2007-08. In case of indirect taxes the trend shows a significant increase for the financial year 2008-09 due to

\footnotetext{
${ }^{45}$ Ibid, s.6. I am indebted to Dr. Pinaki Chakraborty of the National Institute for Public Finance and Policy for assistance in making this link.

${ }^{46}$ Receipts Budget, Annex 12, Tax Expenditure Under the Central Government Tax System, 2004-05, available as of February 12, 2012, at http://indiabudget.nic.in/ub2006-07/rec/annex12.pdf.

${ }^{47}$ Ibid., tables 1 and 2 .

${ }^{48}$ The Canadian Department of Finance Tax Expenditure Reports from 1995 to 2011 were available as of February 12, 2012, at http://www.fin.gc.ca/purl/taxexp-eng.asp. In late 2011 the Parliamentary Budget Officer for the first time released tables showing the distribution of personal tax expenditures among income groups and provinces of Canada. See Office of the Parliamentary Budget Officer, 2011 Reference Tables for Tax Expenditure Distributional Analysis (Office of the Parliamentary Budget Officer, November 10, 2011) (data are for taxation year 2009), available as of February 12, 2012, at http://www.parl.gc.ca/PBO-

DPB/documents/2011_Reference_Tables_Note_EN.pdf.

${ }^{49}$ Union Budget 2007-08, Receipts Budget, Annex 12, Revenue foregone under the Central Tax System: Financial Years 2005-06 and 2006-07, 45.

${ }^{50}$ Union Budget 2008-09, Receipts Budget, Annex 12, Revenue foregone under the Central Tax System: Financial Years 2006-07 and 2007-08, 45-47.

${ }^{51}$ Ibid., at 58.
} 
*The final version of this article is forthcoming in Yariv Brauner and Miranda Stewart, eds., Tax Law and Development (Cheltenham, UK: Edward Elgar Publishing Ltd.)

reduction in customs and excise duties. Therefore, it is necessary to reverse this trend to sustain the high tax buoyancy. ${ }^{52}$

Again, this commentary is strikingly more directive about policy than anything in the Canadian tax expenditure report, which generally provides only brief, anodyne statements about the government's stated policy objectives for each relieving provision, and omits any comment on trends in the number or cost of tax concessions as a proportion of overall spending. ${ }^{53}$ Exceptionally, where legislation or government undertakings require, the report may offer a closer analysis of a particular provision. ${ }^{54}$

Further, unlike the Indian tax expenditure report, the Canadian version is not delivered as part of the federal budget but as a free-standing document released at a different time of the year and with little fanfare on the Finance Department website. Burton and Stewart note that one possible rationale for releasing a tax expenditure report well in advance of the annual budget is to provide citizens and parliamentarians with information that can be considered in the context of pre-budget consultations and advocacy. ${ }^{55}$ In Canada this would make sense if the tax expenditure report was coordinated with the government's fall Economic and Fiscal Update which sets the stage for pre-budget consultations. ${ }^{56}$ However this is not the practice and the most recent report was released on January 9, 2012, following the conclusion of parliamentary budget consultations. ${ }^{57}$ While Canadian federal budgets generally include projected costs for any newly announced tax expenditures, the failure to treat the full report covering all tax expenditures as a budget document means that Canada does not meet OECD or IMF standards of best practice in this area. As reiterated by the OECD in 2010, "[o]ne basic standard of tax expenditure reporting is that data be included in the budget" as this facilitates the essential comparison with direct expenditure data. ${ }^{58}$ Nor has Canada participated to date in the Open Budget Survey of the IBP. In all these respects, the Indian record is superior.

The value of India's report in stimulating discussion and evaluation of tax subsidies seems incontestable. No doubt the methodology, coverage and findings of its report can be subjected to critical analysis and improvement as in any country. Indeed the most recent Open Budget Index has downgraded India from ' $a$ ' to ' $b$ ' on the quality of its reporting, citing a lack of complete information on new tax expenditures proposed in the current budget year. ${ }^{59}$ Nonetheless, compared to having no report and even compared to a country like Canada where tax expenditure reporting has a longer history, it is evident that India's Finance Ministry has improved the transparency of India's budget with this report and has generated new evidence to inform policy making, legislative debate, and civil society advocacy. While fully acknowledging these benefits, I suggest it would be wrong to conclude that all low and middle income countries should necessarily follow this same path, or even that India should necessarily continue its current efforts in the same form in future. In the balance of this chapter I will argue that in weighing

\footnotetext{
52 Union Budget 2009-10, Receipts Budget, Annex 12, Revenue foregone under the Central Tax System: Financial Years 2007-08 and 2008-09, at 58. See also Union Budget 2010-11, Receipts Budget, Annex 12, Revenue foregone under the Central Tax System: Financial Years 2007-08 and 2008-09, at 57.

${ }^{53}$ See, e.g., Department of Finance Canada, Tax Expenditures and Evaluations 2011 (Her Majesty the Queen in Right of Canada, 2012), available as of February 12, 2012, at http://www.fin.gc.ca/taxexp-depfisc/2011/taxexp11eng.pdf.

${ }_{55}^{54}$ See, e.g., the discussion of the public transit tax credit in the 2011 report, Ibid., 48.

${ }^{55}$ Burton and Stewart, supra n. 29, 26.

${ }^{56}$ Tax Expenditures and Evaluations 2011,supra n. 53. The Fiscal and Economic Updates were available as of February 12, 2012, on the Department of Finance website at http://www.fin.gc.ca/access/statement-eng.asp.

${ }^{57}$ The House of Commons Standing Committee on Finance released its report on pre-budget consultations in December 2011: Pre-Budget Consultations 2011, available as of February 12, 2012, at http://www.parl.gc.ca/CommitteeBusiness/CommitteeHome.aspx?Cmte=FINA\&Language=E.

${ }^{58}$ Tax Expenditures in OECD Countries, supra n. 6, 45.

${ }^{59}$ International Budget Project, Open Budget Questionnaire, India September 2009, question 45, available as of February 12, 2012, at http://internationalbudget.org/wp-content/uploads/2011/04/IndiaOBI2010QuestionnaireFinal.pdf.
} 
*The final version of this article is forthcoming in Yariv Brauner and Miranda Stewart, eds., Tax Law and Development (Cheltenham, UK: Edward Elgar Publishing Ltd.)

the value of a tax expenditure report, developing countries should also consider certain implicit costs and risks involved in adopting a budgetary practice pioneered in high income countries.

\section{Universalizing Tax Expenditure Analysis: Some Cautionary Notes}

In this Part, I suggest there is a need for more critical evaluation of tax expenditure reporting as a strategy for advancing development goals in particular countries. It is difficult to argue against transparency at a general level, and this is precisely the problem. Tax expenditure reporting is often recommended to developing countries in a way that suggests it is an unmitigated positive, with no downside risks or contingencies that depend on local circumstances. As a result there is very little space for governments to question the wisdom of this advice or offer reasons why they have chosen not to adopt tax expenditure reporting, without damaging their own credibility as nations that are committed to good governance. This universalism sits uneasily with the broader law and development literature which has cautioned against externally-driven reform efforts that are not attuned to local history and political economy. Trebilcock and Daniels make this point neatly:

Optimal institutions generally, including legal institutions in particular, will often be importantly shaped by factors specific to given societies, including history, culture, political traditions and institutional culture. This in turn implies some degree of modesty on the part of the external community in promoting rule of law or other legal reforms in developing countries and correspondingly a larger role for 'insiders' with detailed local knowledge. ${ }^{60}$

Similar concerns have been voiced in studies of tax reform in developing countries. Richard Bird for example emphasized the folly of attempting to design one-size-fits-all tax policy for developing countries, arguing that " $[\mathrm{t}] \mathrm{o}$ be relevant, policy recommendations need to be geared specifically to the prevailing circumstances and objectives of that country". ${ }^{61}$ Further, Stewart and Jogarajan have written about the role of international experts and organizations in prescribing substantive tax reforms for developing countries and the difficulty of implementing prescriptions that do not enjoy domestic political support. ${ }^{62}$ Based on these studies, we should also be skeptical about imposing a generic best practice relating to tax expenditure reporting that is based largely on the experience and tax policy norms of high income OECD countries.

It would be far too simplistic to suggest that transparency standards are always foisted on developing countries from outside. Domestic governments have varying degrees of autonomy to determine their own budget processes. In the case of India, as discussed in Part III, the Union government's decision to publish a tax expenditure report followed a decades-long internal campaign by Indian tax policy experts. It was not simply a foreign idea brought to India by Western-dominated international financial institutions. In fact India has worked to insulate itself from many of the most coercive economic restructuring pressures those institutions have applied to other Global South countries. In particular, it has pointedly not borrowed from the IMF since the Asian Financial Crisis of the early 1990s. Nonetheless, even in India it would also be wrong to ignore the influence of outside tax and governance expertise.

First, it is notable that in writing about tax expenditures in the 1970s and ' $80 \mathrm{~s}$, Indian commentators borrowed heavily from the writings of U.S. experts. More recently, tax reformers have also acknowledged the influence of international norms in setting the direction of domestic policy. Thus the Kelkar Task Force commented:

In a world of increasingly mobile and frictionless international flow of capital, outward looking national governments soon realised that getting a share of competitive global capital necessitated

\footnotetext{
${ }^{60}$ Supra note $3,12$.

${ }^{61}$ Richard M. Bird, Tax Policy and Economic Development (Johns Hopkins University Press, 1992$), 17$.

${ }^{62}$ M. Stewart and S. Jogarajan, 'The international monetary fund and tax reform' British Tax Review 146-175 (2004).
} 
keeping the tax rates low and tax rules simple - in line with global trends... At the beginning of the $21^{\text {st }}$ century, some truths about taxation have become self-evident...if the objective is to have transparent, efficient and feasible tax administration, then the structure of all taxes should comprise common elements. These are low rates, few nominal rates, a broad base, few exemptions, few incentives, few surcharges, few temporary measures... ${ }^{63}$

In their bid to compete in global markets for investment and trade, Indian policy makers have also understood the value of receiving public praise from international agencies about India's progress on economic reforms. In particular, the IMF's Fiscal ROSC reports are used by investment analysts to guide investment location decisions, and by credit rating agencies in rating sovereign debt. ${ }^{64}$ Formally speaking, these reports are prepared only at the request of a government and are published only with its permission. The Fiscal ROSC on India, from 2001, noted that while the Union Budget met many of the requirements of the Code of Good Practices on Fiscal Transparency, "there is no information on tax expenditures..."65 In the years following the Fiscal ROSC IMF papers continued to criticize India's pervasive use of tax incentives and exemptions, arguing that they distort investment decisions, erode revenues, and constrain growth. ${ }^{66}$ Similarly the World Bank's 2003 report on India stated:

Services and agriculture need to be brought into the tax net, and lower tax rates must be complemented with the elimination of exemptions. Exemptions doubled from 1996 to 2002/3. ${ }^{67}$

Given these kinds of highly visible statements, the Indian government's decision to embrace tax expenditure reporting should not be seen as entirely home grown but rather as a combined product of external and internal norms and politics. In other countries where international donors and agencies have more direct leverage, the potential disadvantages or risks of importing tax expenditure analysis may be greater.

At least three such risks can be identified. The first is that advocates may overstate the effectiveness of tax expenditure reporting as a strategy either to improve policy or to strengthen democratic oversight of the budget. This might be seen as a relatively mild downside that does no active harm to the receiving country. However I argue it is more troubling in light of a second risk that with tax expenditure reporting, and particularly the identification of a benchmark norm, a country may also import ideas about what constitutes good tax policy. That is, it may function indirectly to expose countries to criticism for making tax policy choices that depart from received international standards. Finally, the production of tax expenditure reports consumes valuable staff time and energy. Given the challenges that many developing countries face to administer their budget and revenue collection processes, new demands should not be added on a mere hope that some benefit may flow. Each of these disadvantages or risks is elaborated below.

\section{Exaggerating the Potential of Tax Expenditure Reporting to Effect Change}

Surrey and other early tax expenditure theorists had high hopes that greater transparency would trigger more rational policy making. This same hope is evident in the recent literature calling on developing countries to adopt tax expenditure reporting, as reviewed above in Part II. What is less fully conveyed is how difficult it has proven to be in practice for OECD countries such as the US, Canada, and the United Kingdom to make lasting reductions in the number or size of their tax expenditures. ${ }^{68}$ Often politically easier to pass into law than direct expenditures, they also tend to evade critical review and

\footnotetext{
${ }^{63}$ Kelkar Task Force on Direct Taxes, supra, n. 40, 67.

${ }^{64}$ See Philipps and Stewart, supra note 18, 812-815.

${ }^{65}$ IMF Fiscal ROSC for India, 2001, para. 16. This gap has since been remedied, as discussed in Part III above.

${ }^{66}$ See, e.g., Hélène Poirson, The Tax System in India: Could Reform Spur Growth? (IMF Working Paper WP/06/93, 2006), 15; and IMF Survey August 7, 2006 (Vol.35, No.15), 238.

${ }^{67}$ World Bank, India: Sustaining Reform, Reducing Poverty (July 14, 2003), 53.

${ }^{68}$ For a review of trends in 10 countries, see Tax Expenditures in OECD Countries, supra n. 6, Ch.4.
} 
*The final version of this article is forthcoming in Yariv Brauner and Miranda Stewart, eds., Tax Law and Development (Cheltenham, UK: Edward Elgar Publishing Ltd.)

evaluation once enacted. ${ }^{69}$ In making the case for transparency there is perhaps a natural tendency to focus on its potential benefits. What the advocates of tax expenditure reporting often understate however is the political barriers and costs to changing certain parts of the tax code that may be widely viewed as an entitlement or as supporting a culturally valued way of life, or that may be defended vigorously by narrow constituencies who benefit from concessions.

Recent tax reform debates in India demonstrate the challenges of effecting base-broadening tax reform. The draft Direct Tax Code of 2009 proposed significant changes to the personal income tax of the sort that would appeal to many OECD-style reformers. These included eliminating deductions for home mortgage interest and reducing special treatment for capital gains, while using the increased revenue to reduce the general tax rate. ${ }^{70}$ After approximately a year of consultation in which the government reportedly received more than 1,600 representations, a 2010 reform proposal was released with a much scaled back vision. ${ }^{71}$ Home mortgage deductions and capital gains relief will remain largely as is, as will tax rates. ${ }^{72}$

If the 2009 proposals were in fact defeated in part by interest group lobbying, India certainly would not be alone in that experience. In Canada the 1967 report of the Carter Commission which proposed a move away from source-based taxation toward a comprehensive tax base met a similar set of compromises following intensive advocacy by the business, investment and tax professional communities. $^{73}$ The point in both cases is that the process of tax reform ultimately has little to do with what technocratic information is available to policy makers or the public, and much more to do with a society's political economy at a particular historical juncture. This is a key reason why tax expenditure reporting in many OECD countries has not succeeded in containing the number or cost of these measures, and why Western tax scholars are now grappling with the question of what other institutional changes could be introduced to discipline the use of the tax system as a spending instrument. ${ }^{74}$ Given that tax expenditure reporting is not a costless exercise, countries would be well advised to weigh the benefits and identify clear objectives and strategies for using a tax expenditure report to inform policy or public debate.

\section{Importing Tax Policy Ideas Through the Benchmark Norm}

The second concern is that in adopting tax expenditure analysis a government may implicitly endorse a set of assumptions about what its tax and broader fiscal system ideally should look like. A tax expenditure is by definition a deviation from normal or benchmark tax rules. Many of the classic writings and OECD prescriptions assume the broadest possible tax base as the norm, with fully neutral treatment

\footnotetext{
${ }^{69}$ Ibid., 31-34. See also Christopher Howard, 'The Politics of Tax Expenditures in Wealthy Democracies,' in Lisa Philipps, Neil Brooks, and Jinyan Li, eds., Tax Expenditures: State of the Art (Canadian Tax Foundation, 2011) 7:1; and Edward D. Kleinbard, 'The Congress within the Congress: How Tax Expenditures Distort our Budget and our Political Processes' 36 Ohio Northern University Law Review 1 (2010).

${ }^{70}$ For an overview, see KPMG LLP, Direct Tax Code 2009_Highlights.

${ }^{71}$ See KPMG LLP, Update on India's Direct Tax Code Bill (November, 2010). The 2010 Direct Taxes Code was introduced in the Lok Sabha as Bill No. 110 of 2010 on August 30, 2010, and if approved, it will be effective as of April 1, 2012 (cl.1(3)), (It was available as of February 12, 2012, at http://164.100.24.219/BillsTexts/LSBillTexts/asintroduced/DTC\%20\%28110\%20of\%202010\%29\%20To\%20be.pdf .)

${ }^{72}$ For a summary, see KPMG LLP, Direct Taxes Code-2010, available as of February 12, 2012, at http://www.kpmg.com/in/en/whatwedo/tax/pages/directtaxcode.aspx. [already stated in previous footnote] ${ }^{73}$ See Leslie T. MacDonald, 'Why the Carter Commission Had To Be Stopped,' in Neil Brooks, ed., The Quest for Tax Reform (Carswell Company Ltd., 1988), 351; and Linda McQuaig, Behind Closed Doors: How the Rich Won Control of Canada's Tax System...And Ended Up Richer (Penguin Books Canada Limited, 1987).

${ }^{74}$ See, e.g., Burton, supra n. 11; Mark Burton, 'Capturing Contemporary "Democracy": The Shortcomings of Australian Tax Expenditure Management and Their Ideological Foundations, ' in Lisa Philipps, Neil Brooks, and Jinyan Li, eds., Tax Expenditures: State of the Art (Canadian Tax Foundation, 2011) 7:1; and Edward D. Kleinbard, 'Tax Expenditure Framework Legislation' 63 National Tax Journal 353 (2010).
} 
of different sectors, taxpayers, and forms of production and consumption. They also assume that taxbased programs can and should be replaced by direct government spending if this will achieve the goals of the program more effectively and transparently. These background assumptions are acknowledged to represent an ideal model rather than practical reality even by OECD-based analysts. They may be even less appropriate in a low income country with a large impoverished population, highly uneven industrial development, and limited or non-existent public safety net. That is, tax concessions designed to protect basic consumption of the poor or to support particular development objectives may be more justified or at least harder to replace with direct spending programs in low income countries than in wealthy ones.

This tension was captured for example in the reactions of one Indian commentator to the Kelkar reports. Economist and senior civil servant Madhav Godbole praised the Task Force's recommendation that a rigorous cost-benefit analysis be applied to any proposed new tax expenditures. ${ }^{75} \mathrm{He}$ went on, however, to object to its proposed reduction of tax concessions for saving, educational expenses and medical expenses as overly harsh. With respect to the first of these he pointed out,

...there is no social security net in India unlike in a number of other countries. Drawing lessons from disparate countries on the important question of tax exemption for saving instruments and making them applicable to India may therefore be counter-productive. There is certainly room for rationalization of some of the existing incentives...but to go to the other extreme and abolish all incentives altogether, as suggested by the task force, is certainly neither warranted nor will it be in the national interest. ${ }^{76}$

Similarly, Joosung Jun defends generous tax expenditures in South Korea as the most rational tax structure for that country, not because they encourage desirable economic behaviours but because they make the tax burden more equal between workers in the formal and informal sectors, thereby stemming tax evasion and encouraging taxpayers to enter the formal economy. ${ }^{77} \mathrm{He}$ rejects the standard international prescription to eliminate tax preferences, arguing that their base-protection effects offset any revenue or efficiency costs which in his view are "overstated". 78

The need to define a benchmark that suits the domestic context does not go entirely unrecognized by Western-based experts. World Bank analyst Li Swift, for example, acknowledges that the benchmark norm may need "some modification...corresponding to specific economic conditions in transition and developing countries..." ${ }^{79}$ Likewise there is an active debate among tax scholars in the West about whether developing countries should be discouraged outright from using tax incentives to promote investment and growth, or whether the main focus should be on better design of incentives to prevent abuse and achieve state goals more effectively. ${ }^{80}$ Yet these nuances are side-stepped in much of the literature that promotes tax expenditure reporting by developing countries, and a zero-incentive norm is implicitly or explicitly adopted as the universal ideal benchmark against which a tax system should be evaluated. ${ }^{81}$ Countries may also be drawn to a broad benchmark because it is the simplest to define. Doing so, however, may place domestic policy makers on the defensive when their tax systems are then

\footnotetext{
${ }^{75}$ Madhav Godbole, 'Task Force Reports on Direct and Indirect Taxes: Some Issues' 37:49 Economic and Political Weekly 4884-4890 (December 7-13, 2002), 4884.

${ }^{76}$ Godbole, Ibid., 4886.

77 Joosung Jun, 'Korea's Tax System: A Growth-Oriented Choice,' in Roger H. Gordon, ed., Taxation in Developing Countries (Columbia University Press, 2010) 220, 245-246.

${ }^{78}$ Ibid, 245.

${ }^{79}$ Supra note 22, 19.

${ }^{80}$ See, e.g., Reuven Avi-Yonah and Yoram Margalioth, 'Taxation in Developing Countries: Some Recent Support and Challenges to the Conventional View’ 27 Virginia Tax Review 1 (2007-2008).

${ }^{81}$ Yariv Brauner makes a similar point in 'International Trade and Tax Agreements May be Coordinated, But Not Reconciled' 25 Virginia Tax Review 251 (2005-2006), esp. 297-302, where he argues against using a country’s tax expenditure report to determine if it has subsidized exports contrary to the WTO, because we should not expect a consensus among (or even within) countries about how to define the benchmark or normal tax system, nor are measurements of the cost of tax expenditures sufficiently reliable or comparable to direct subsidies.
} 
*The final version of this article is forthcoming in Yariv Brauner and Miranda Stewart, eds., Tax Law and Development (Cheltenham, UK: Edward Elgar Publishing Ltd.)

evaluated by these same outside agencies. In this way, without explicitly imposing any particular tax policy, it may impinge on a country's policy autonomy.

\section{Increasing Administrative Burdens}

Tax expenditure reporting requires an investment of time by expert staff. While these costs may be negligible to a high income country with a large civil service, their significance for other countries should not be discounted. For example Li Swift cautions that "It takes at least two years to develop a basic tax database for initial estimating [of?] tax expenditures. Therefore, any development relating to tax database for this purpose must be planned and begin as soon as possible". ${ }^{82}$ Many developing countries have only modest staff resources available to manage their budget processes. ${ }^{83}$ In a particular case, the preparation of tax expenditure reports may not be worth its opportunity costs. Case studies on tax reform and development have identified a list of other priority investments that countries should make in order to strengthen their tax systems, many of which focus on improving administrative capacity rather than analyzing or refining tax policy. ${ }^{84}$ As Richard Bird has underlined, tax administration challenges render many policy prescriptions for developing countries impractical. ${ }^{85}$

Strengthening tax administration may require investing in information technology and human capital through training and better pay to retain skilled staff. Further, tax personnel are increasingly called upon to participate in international fora where treaties, soft law norms, and strategies for countering tax avoidance and evasion are being negotiated or discussed. ${ }^{86}$ Especially because developing countries have not yet attained an equal place at the table in global tax governance, it is important that they participate and make their perspectives heard wherever possible. ${ }^{87}$ The leaders of finance departments and revenue agencies in developing countries will often have to make difficult choices about how best to deploy limited human and operational resources. In this context, it is not obvious that gathering, analyzing and reporting tax expenditure data provides the best value for money.

\section{Conclusion}

This chapter examines the rise of tax expenditure reporting in countries of the Global South, and particularly within India as an emergent economic power, and describes the sources of international and domestic expertise that have actively called for this type of reform. While recognizing the potential benefits of greater transparency, I also suggest that more critical reflection is needed about its potential risks and costs for particular countries. My critique extends the point made by other tax scholars, that generic reform prescriptions of international bodies may be poorly adapted to the local circumstances of developing countries, and may impinge on their political autonomy to set tax policy. As Allison Christians has written,

[i]nternational tax policy formulation has almost exclusively been the purview of experts from developed countries, despite periodic efforts to achieve some measure of participation by less developed countries. As a result, the economic, social, and legal context of these less developed

\footnotetext{
${ }^{82}$ Li Swift, 'Managing the Effects of Tax Expenditures on National Budgets' (2006), Supra note 12, 22.

${ }^{83}$ See Richard Allen, 'The Challenge of Reforming Budgetary Institutions in Developing Countries,' IMF Working Paper WP/09/96 (May 2009).

${ }^{84}$ See Trebilcock and Daniels, supra n. 3, 212-235.

${ }^{85}$ See Bird, supra n. 61, 189-193.

${ }^{86}$ For an overview of these fora, see UN Social and Economic Council, Strengthening of institutional arrangements to promote international cooperation in tax matters, including the Committee of Experts on International Cooperation in Tax Matters: Report of the Secretary General (March 18, 2011).

${ }^{87}$ See Allison Christians, 'Tax Policy in a Time of Crisis: Policy Leadership from the OECD to the G20' 5 Northwestern Journal of Law and Social Policy 19 (2010), for a critical analysis highlighting the historical exclusion of non-OECD countries from international tax policy making processes and the continuing difficulty for poor countries of gaining voice through the G20 or other global governance institutions.
} 
*The final version of this article is forthcoming in Yariv Brauner and Miranda Stewart, eds., Tax Law and Development (Cheltenham, UK: Edward Elgar Publishing Ltd.)

countries may be too easily overlooked as international consensus evolves regarding the strategies nations should employ to raise revenues in the context of a global economy. ${ }^{88}$

Tax expenditure reports may fall into this trap. They may also be far less effective than hoped at stimulating policy change or improving transparency and oversight, as the experience of high income countries such as Canada shows. Moreover, tax expenditure reporting consumes resources which might be better deployed in some other fashion, like detecting avoidance, negotiating tax treaties, or smoothing compliance for taxpayers.

As a regulatory norm transparency often avoids controversy and escapes critical analysis because it presents a relatively value neutral and non-interventionist approach to governance. For the same reasons it may appear to transcend local differences and provide a model for universal reform. There are good reasons to support greater transparency about tax expenditures. However, exactly what should be transparent, to what ends and for whose benefit are political questions that should be answered to some extent at the level of national budget institutions. This chapter has also identified the need for countries to analyze whether the potential benefits of tax expenditure reporting outweigh the costs to them. When developing countries do embark on tax expenditure reporting they are well advised to consider their own objectives, priorities and resources and to design the exercise to fit these.

88 'Global Trends and Constraints on Tax Policy in the Least Developed Countries' University of Wisconsin Legal Studies Research Paper Series, Paper No. 1086 (2009), 31. 